\title{
Public-Private Collaboration for Corporate Globalization of Pakistani Companies
}

\author{
Jawaid Ahmed Qureshi \\ SZABIST, Karachi \\ Amanat Ali Jalbani \\ SZABIST, Karachi
}

\begin{abstract}
Purpose: The purpose of this paper is to critically examine some dimensions of corporate globalization aligned in the three integrated objectives that include: discovering the facilitation and support mechanism (in terms of technical capacity-building and financial assistance) of public and private sectors institutions to uphold exporters and globally expanding Pakistani companies, and the extent of public-private (and specifically corporate-government) collaboration for developing international markets for Pakistani products and businesses..

Methodology/Sampling: The research design of this study is mix methods. It employs qualitative cum quantitative approaches. The research appears exploratory during qualitative phase of investigation. Media content analysis through renowned news papers is undertaken to observe the collaboration and delightfulness or grievances of those practitioners with MoC and TDAP.

Findings: The findings of the probe discover that the facilitation programs of public bodies to nourish exporters and corporate global expansion of Pakistani companies remains limited cum infirm.

Practical Implications: The private sectors is coming forward to help itself, and the public-private collaboration (or specifically corporate-government alliance) is undermined.
\end{abstract}

Keywords: Public-Private Collaboration; Corporate Globalization of Pakistani Companies. JEL Classification: M100, F600, F640

\footnotetext{
* The material presented by the authors does not necessarily portray the viewpoint of the editors and the management of the Institute of Business \& Technology (IBT).

* Jawaid Ahmed Qureshi

* Amanat Ali Jalbani: Jalbani@szabist.edu.pk

CJMSS is published by the Institute of Business and Technology (IBT). Main Ibrahim Hydri Road, Korangi Creek, Karachi-75190, Pakistan.
} 


\section{INTRODUCTION}

Public-private partnership (PPP) or such collaboration has been widely used in many parts of the world. It has many dimensions. Sometimes the public sector invites the private sector to invest or technically assist in an infrastructure developmental project or a technical project, such as minerals exploration or refining related projects. On the other hand, the private sector also collaborates with the ruling or government sector to attain similar objectives. Such a partnership is also intended to subside operational risks, since the technical competence, skills, and expertise of the partners are involved. In some situations, public sector does not invest but just facilitate the private sector to avail financing from banks and lending entities by providing guarantees, or leasing its land or other assets to the private partners, or curtail taxes and impart tax breaks to support private partners (Zheng, Roehrich, \& Lewis, 2008). The other forms of collaboration between the two sectors take place for the sake of mutual cooperation extended to develop something or accomplish certain goals. In the matrix of export development or promotion of trade and industry, the public sector entities spur and invite the private sector bodies to deliberate, discourse, and come across with resolutions to fortify the various sectors of the economy. Same is the case in Pakistan, ministry of commerce (MoC) and Trade Development Authority of Pakistan (TDAP) have liaison and strategic cooperation to build, upgrade, and nourish exports from Pakistan through its exporters cum globally expanding companies of Pakistan that globalize their net to accelerate their exports.

Globalization has opened new avenues of opportunities for the masses of populace, businesses, and companies/agencies around the globe. People of the world and companies can trade, invest, finance, share and exchange cultural values and their concerns, and move around it for travel and seek immigration. This is all possible due to globalization (International Monetary Fund, 2014; Qureshi, 2014; Anjum, 2011; European Commission, 2005; Jeffus, 2003). In one way, the globe has been squeezed as the distances have been shrunk due to advent of faster get airlines and especially telecommunication, and the internet revolution. It has become a global village having a global community. Many argue about the notion of a border-less state or one world, so-called global economy (Sklair, 2000 as cited by Jeffus, 2003). There are institutions that uphold free market economy and barriers-free market to promote fair trade without high tariff or customs duties and non-tariff or technical standards related barricades. Such global institutions or drivers of the global economy consist of World Trade Organization (WTO), United Nations (UN), World Bank (WB), International Monetary Fund (IMF), and many others (Qureshi, 2014; World Trade Organization, 2014).

Countless intercontinental companies have emerged, which are engaged in cross border trade and business, and appear eager to take their share in the global marketplace. In a bid to gain competitive vitality and strengthen their business position, many companies especially entrenched firms go global and set up their offices, sales, distribution, and marketing subsidies abroad, and many have facilities abroad too. Such network assists them in raising their export sales, market share, and global competitiveness, while they step up beyond exports. In this way, the term corporate globalization has emerged (Qureshi, 2014; Li, Qiu, \& Wan, 2011; Hill 2005, 2006). But this has also led to the concerns of corporate global dominance and capture of the world by elite class and the ruthless intercontinental companies. The global trade is not easy and so fair any more, as it is highly regulated and the cost of compliance on the global standards and certifications like International Standard Organization (ISO) 9000 and series of its other benchmarks, Euregap (applied in farm products businesses), Good Manufacturing Practices (GMP - applied in healthcare businesses), and so on to ensure quality, hygiene, 
environmental safety (for avoiding or minimizing industrial hazards, toxic wastes, and pollution), labor rights cum better working conditions, consumer safety and rights, fair trade practices, etc. have put a heavy cost on their effective execution. This has led to clear cut incompetitiveness of the staggering under-developed economies, which they are unable to cope. Thus, the majority of the opportunities are grabbed by the already developed cum powerful states and global businesses, but somehow by developing states and their companies too. Such issues tend to be mega challenges for globalization and lead to serious concerns for antiglobalization think tanks (Anjum, 2011; Gilman et al., 2011).

The governments of developed countries as well as developing countries realized long ago that it is imperative to aid their exporters technically and financially to ensure their sustainable development in the export markets. They provide grants and subsidies on exports in the heads of research and development (R\&D), standardization cum certification of excellence, packaging, branding, export marketing, and freight outgoings for export consignments, establishing retail outlets and warehouses abroad, and so on. They support them by lending reduced-rate loans for exports, duty-free import of plants and machinery, and so forth (Ministry of Commerce, 2013, 14; Trade Development Authority of Pakistan, 2013, 14). Towards attaining the strategic objectives of the public sector for raising exports of goods and services to consolidate its industries and commercial entities, the private sector also lean forward to hand-hold them. The various chapters of chamber of commerce, trade associations, and their federal head-quarter provide all out support and facilitation system to exporters and their globally expanding companies. They lodge trade inquiries/leads received from their commercial consulates or private sources; organize discussions, seminars, workshops, and training programs; arrange inland and overseas expos to flourish their exports; and make a liaison with national and international agencies cum diplomatic staff to highlight their problems or issues and seek meaningful solutions to thrive their members and economies by adding foreign currency reserves in their treasure balance (Qureshi, 2014). This is why, the developed countries as well as developing countries spur strategic alliance/collaboration of their public and private sectors (inclusive of corporate-government sectors) to uphold their global trade.

\subsection{Research Problem}

Countries of the world assist their exporters to enhance their exports and market share in the world market. There are many companies that go beyond exports or one step ahead of exports and expand their operations and network in other countries. Indeed they turn as global businesses; such status not only offers economic gains to them but their domestic economies and markets where they operate. This study intends to uncover the institutional assistance mechanism (for technical capacity building and financial aid) devised by the public institutes particularly ministry of commerce (MoC) and Trade Development Authority of Pakistan (TDAP) and the private sector bodies to flourish them, and the level of collaboration cum cooperation between the public and private, particularly corporate-government sectors, which is considered as a indispensible for their success.

\subsection{Research Objectives and Scope}

The three integrated/synthesized objectives of this study are to uncover the institutional support system of public and private sectors, and the extent of public-private (and specifically 
corporate-government) collaboration for developing international markets for Pakistani products (by upholding exporters and their overseas expansion). These objectives are met through one-on-one interviews, media content analysis, and later on, quantifying the outcome of a wide scale survey from the participants of the study. Actually, the grievances of the business community and the loopholes in the public institutions' facilitation mechanism are unearthed by media forces. That is why, the technique of observations through analyzing published and electronic media reports has been chosen. The scope of the study encloses it to above described dimensions only.

\subsection{Research Questions}

The key questions of the study are investigated through literature and primary data; they include:

- What are the policies and programs of technical and financial assistance exercised by public sector institutions especially ministry of commerce and Trade Development Authority of Pakistan to nourish exports through exporters and globally expanding Pakistani companies?

- What are the initiatives of the private sector in Pakistan to escalate export trade (through exporters and globally expanding Pakistani companies)?

- Is there any meaningful or effective collaboration between public and private sectors (and especially corporate-government) to uphold corporate global expansion?

\subsection{Research Methodology}

The research design comprises of synthesis of hybrid/mix methods of enquiry that comprise qualitative cum quantitative research paradigms. Sequentially, the investigation tends to be exploratory in the context of Pakistan and utilize semi-structured interviews and observations through media content analysis. Then after clarifying the initial concepts and queries, it becomes an explanatory probe and avails a structured survey. It is a cross sectional study.

\subsubsection{Data Collection}

The secondary data is gleaned from authentic and relevant published sources and the primary data is assembled through one-on-one semi-structured interviews, observations via media content analysis, and structured survey from multiple populations. They comprise of representatives of ministry of commerce $(\mathrm{MoC})$ and Trade Development Authority of Pakistan (TDAP) dealing with foreign trade, exporters and globally expanding companies of Pakistan operative in top-five export sectors of the country inclusive of textile, leather, rice, seafood, and wheat (Pakistan Bureau of Statistics, 2013; Pakistan Economic Survey, 10-11; 11-12; 1213). The textile sector contains sub-sectors as well.

The wheat sector enjoys being a member of food group tends to be in top export sectors in years when there is a bumper crop, and Trading Corporation of Pakistan (TCP) allows its export. The samples consist of ten officials, five each from MoC and TDAP and twenty five officials from top-5 export sectors in Pakistan, five from each category/sector chosen 
through convenience sampling procedure, as per the formula advised by Luca (2013). The total population of public and private limited companies operative in those five sectors stands 5270 companies (Securities and Exchange Commission of Pakistan, 2013). Their characteristics that qualify them for interviews include: top managers with 3-5 years' experience at that position in their existing company (their companies include MoC, TDAP, and companies of top-five export sectors). In media content analysis, the news from renowned media sources, particularly news papers was collected over the span of three years from the year 2009-10 to 2011-12.

From content assessment perspective, it is a longitudinal study. For survey, five plus percent samples are chosen through proportionate stratified random sampling that is prescribed by deVaus (2003, as cited by Saunders et al., 2011), which ensures participation of all the subsectors of the populations in equal proportion. The questionnaires address all the pertinent variables. They were pre-tested for determining their cognition by respondents and eliminating any bugs or snags. Prior to survey, pre-testing of the questionnaire and scale were also done to examine their reliability via Cronbach Alpha test. The measurement scale employed includes 5-point Likert scale. Moreover, the method of test-retest is applied to confirm reliability. Ultimately, the results or findings of the probe are matched with those of the analogous enquiries in a bid to learn whether they converge or discriminate from them.

\subsubsection{Data Analysis}

The data analysis techniques include interpretation of interviews (aggregate to unique responses); observation through content analysis; Reliability Test for determining soundness of the measurement tools; Multiple Regression Analysis to find significance of the model and individual variables; and Oneway ANOVA to learn about equivalence of the means of the five populations taken for survey.

\subsection{Rationale and Value of the Research}

Regarding foreign trade and economic growth, numerous authors emphasized on exports, but this probe goes one step ahead by analyzing the role of institutional support framework (public and private entities and their strategic collaboration) to exporters and globally expanding companies. This research can add value to them, pertinent policy makers, and academia by identifying the strengths as well as weaknesses or lacunas in the system. In addition, it posits the strategic ways to remove those loopholes, enabling those companies to play better roles at individual level, and pave the way for sustainable economic development of the country.

\section{LITERATURE REVIEW}

Many authors unanimously agree that globalization is about the socio-economic ties among nations of the world for the sake of development in all the realms of knowledge and technology including education, health, commerce and industry, business and finance, entertainment, culture, media, legal framework, and so forth (Anjum, 2011; Sklair, 2000 as cited by Jeffus, 2003). Globalization is the age of technology since it has outgrown from scientific advancements in means of communication, travel, tourism, and other domains. Over the period of time, every product in every industry is getting more and more modernized. World trade encompasses various strategies and modes of operations for import and export. Numerous 
companies have gone global. They usually resume their international operations through exports and imports, directly or indirectly through the assistance of some agents, distributors, or brokers. In the wake of initial success and relationship network abroad, they set up offices serving as sales subsidiaries, or full-fledged sales and marketing or distribution subsidiaries, branches, or even operational or manufacturing facilities overseas.

However, there exist companies that believe in outsourcing and therefore, keep a control over the supply of product which they receive from any authorized channel from global sources. Nike reflects the perfect example for that. It owns only design and research and development (R\&D) units, while it outsources from worldwide sources and some independent company does marketing for it (Nike, 2014). There are many companies that adopt some other business models or modes of business operations like licensing of manufactured products, franchising of service-oriented products, joint ventures (JVs) with overseas partners to capitalize their knowledge, expertise, and relationship networks cum resources, and mergers, takeovers, and acquisitions of rival brands and companies to ensure greater penetration and share in the marketplace. The bigger the company, the greater the investment and risk it can take.

There are intercontinental companies which are so mighty in terms of sales, number of worldwide employees, and network of operations that they appear stronger than many smaller independent states. For instance, WalMart and Exxon Mobil are bigger and stronger than Thailand, Czech Republic, Pakistan, Peru, and New Zealand as their annual sales exceed the gross domestic products (GDPs) of them (Trivett, 2011). Globalization and especially corporate globalization offers both opportunities and threats ( $\mathrm{Li}$, Qiu, \& Wan, 2011). The companies around the globe have to comprehend the shifting rules of the global game. As expounded in the introduction part, the companies of the developing and under-developed countries (mainly facing resource constraints) have to prudently strategize to meet the heavy cost of compliance with international standards of quality, hygiene, environmental concerns, safety, labor and work standards, consumer rights, fair trade practices, and so forth.

\subsection{Corporate Global Expansion of Pakistani Companies}

In today's era of globalization and technological revolution, along with advanced countries, many of the developing and under-developing countries including Pakistan has availed the cutting edge of techno-modernization. There are many companies of Pakistan from textile and pharmaceutical sectors that have registered their brands in fifteen plus countries around the globe (Federation of Pakistan Chambers of Commerce \& Industry, 2014). Leather, sports goods, surgical goods, processed food, carpets, information technology, and electronic media sectors have gone global. They enjoy branches, subsidiaries, outlets, representation, distribution channels, and even facilities in many continents. Many domestic banks of Pakistan have overseas branches to serve their global customers (Qureshi, 2014). They are strategizing the state-of-the-art tools to thrive their business and capture their share in the global marketplace. Many of such companies stretched their network abroad in the wake of domestic success and after being entrenched businesses. They capitalized their rapport with overseas channel partners like buyers, marketers, and distributors, and suppliers, consultants, and service providers. Indeed, many of them were spurred to extend their operations to particular countries upon the insistence of their relationship or network partners (Ibid, 2014). This way they become able to understand individual customers and markets in a better way, and comprehend their 
culture, competition, and regulations governing businesses. This is the way of going global that was very well understood and executed long ago by the intercontinental companies.

The era of globalization and free trade regime under World Trade Organization (WTO) enable them to leverage such opportunities and evade tariff and non-tariff or technical obstructions to trade. This is the reason, many of the multinational companies and global businesses are ranked bigger than many smaller economies. The good thing is that many Pakistani companies have come on that track. Albeit the strategy of global expansion has never been so easy, it calls for core competitive edges, inventions cum innovations, resource-base, marketing and business research, wielding learning, stronger experience curve, and long-run commitment based on relationship network and trust (Johanson \& Vahlne, 2009). Eventually, the facilitation mechanism supplied by public entities substantially aid them in attaining new heights of success (Qureshi, 2014).

\subsection{Government's Role in Global Expansion of Pakistani Companies}

Like the governments of other developing countries, Government of Pakistan also crafts a strategic trade policy to uphold the global trade and commerce of the country. Ministry of commerce, Trade Development Authority of Pakistan, ministry of industries, ministry of finance, board of investment, and other economic institutions collaborate with each other as well as the private sector representatives including prominent businessmen belonging to chapters of various chamber of commerce and trade associations to raise foreign investment in different sectors in Pakistan, and aid domestic firms to export their products. In the wake of success and enriched learning cum experience curve, many of the exporting companies switch to the track of resuming global operations and expansion. This section analyzes the public and private institutions' support framework and their strategic collaboration to such companies for their success.

\subsubsection{Trade Policy Incentives}

The government designs trade policy inclusive of import order, export order (i.e. such rules and regulations/procedures), and export goals and strategies to accomplish its periodic targets of exports and enhance its value in the global trade and marketplace, which eventually lead to its sustainable economic development. In several years, government announced a trade policy. The latest strategic trade policy framework (STPF) envisioned a medium term framework for three fiscal years from 2012-2015 [for 2012-13, 13-14, and 14-15], and targeted export target of Rs95 billion in three years. In addition to this policy, some features of trade policy 20092012 are also highlighted, since they are integrated. Some of the core incentives and facilities offered to the exporters, industrialists, and some particular industrial zones such as, export processing zones (EPZs) under various conditions consists, duty drawbacks on re-exports and waiver of customs duties and sales tax on import of certain inputs and capital goods, Manufacturing in Bond (MIB) for duty free import of input goods for the sake of exports, grants for products' registration, development, branding, and marketing overseas; grants for opening offices and retail outlets abroad; establishing research and development (R\&D) fund for technology up-gradation, skill development, and management system up-gradation; establishing service export development fund; establishing warehouses in major world markets for Pakistani products; grants for procuring counseling services of consultants for export of selected items; grants for acquiring standardization certificates; and initiatives to promote 
Pakistani products through organizing international fairs domestically and participating in such expos overseas etc.

\subsubsection{Trade Assistance by Foreign Embassies and Consulates}

The embassies, consulates (along with their commercial sections), and trade missions of Pakistan spread all over the world assist Pakistani exporters and its globally expanding companies (engaged in export operations too), or potential firms by imparting trade leads, technical knowledge about quality, other standards, packaging, tariff/customs duties, and trade cum economic statistics of individual countries, etc. They also aid them in exploring and developing new and potential markets overseas; exporting Pakistani services and manpower; establishing liaison with overseas chambers, trade bodies, authorities, and buyers and suppliers; setting up display centers and warehouses abroad for Pakistani products; and other services as envisaged in trade policy. They assist TDAP in arranging travel programs of Pakistani exporters' delegations in overseas expos and investment conferences; strive for attracting foreign importers and investors in domestic expos and investment conferences; attempt to bring foreign direct investment (FDI) to Pakistan; showcase Pakistan's soft image to the world; and present statistics, trade directory, travel guide, and info to potential overseas investors on doing business in Pakistan (Qureshi, 2014).

\subsubsection{Trade Assistance by Trade Development Authority of Pakistan (TDAP)}

Trade Development Authority of Pakistan (2014) is the apex authority to promote export trade from Pakistan. It operates in liaison with ministry of commerce, chambers of commerce, trade bodies, and other public bodies. It develops strategic plans for raising exports and imparts various services like: disseminating products' inquires from overseas importers; developing database of registration of domestic exporters and overseas importers; imparting technical info about foreign trade and regulations, market research, and other services as envisaged in trade policy. It is also responsible for disbursing subsidies and travel grants to exporters participating in overseas fairs, expos, and conferences; establishing liaison with foreign trade promotion agencies like, Japan External Trade Organization (JETRO), Japan International Cooperation Agency (JICA), Pakistan-Malaysia Friendship Association, etc.; establishing liaison offices abroad and linkages with buying houses like, Walmart Global Procurement, Mondial Orient Ltd., International Buying Sourcing (IBS), etc.; establishing World Trade Organization (WTO) cell to nourish free trade regime; offering assistance in settlement of trade disputes; HS-Code (Harmonized System Codes for customs duties on various items), and statutory regulatory orders (SROs) of the government, and info on doing business in Pakistan.

\subsubsection{Bilateral Trade and Free Trade Agreements (FTAs), and Trade Blocks}

Pakistan has established magnificent foreign relations with various countries and bilateral cum multilateral trade rapport with China, Saudi Arabia, Iran, UAE, Malaysia, Indonesia, India, Japan, USA, England, Germany, France, and many other countries. She capitalizes these ties to accomplish her sustainable trade growth and economic development. Moreover, Pakistan has signed various ententes, memorandum of understanding (MoUs), Free Trade Agreements (FTAs) and Preferential Trade Agreements (PTAs) with many countries to offer and receive a concessional tariff on export as well as import of various products, whereas some remain 
yet pending. The list of such FTAs and PTAs is portrayed here (Ministry of Commerce, 2013; President of Pakistan, 2013): Pakistan signed FTAs with China, Malaysia, Sri Lanka, and Afghanistan; it signed PTAs with Iran and Mauritius; while its pending FTA is due with India, and its pending PTAs appear due with Indonesia, Jordon, and Morocco.

In addition to them, it has some other ententes like: Afghanistan-Pakistan Transits Trade Agreement (APTTA), South Asian Association for Regional Cooperation (SAARC), SAARC Preferential Trade Agreement (SAPTA), Association of South Asian Nations (ASEAN), South Asia Free Trade Area (SAFTA), and Developing 8 (D8). However, Pakistan is also seeking the FTA or cooperation with Gulf Cooperation Countries (GCC). Pakistan is also the beneficiary of Generalized System of Preference (GSP) treatment that offers subsidized tariff to the developing countries to support their economic well-being, export growth, and industrial development. It is given by countries like USA, Canada, Japan, Australia, New Zealand, UK, and EU (International Trade Center, UNCTAD/WTO \& Small \& Medium Enterprises Development Authority, 2007).

\subsection{Initiatives by the Private Sector to Strengthen Exporters and Corporate Globalization of Pakistani Companies}

The prime representative of the private sector, Federation of Pakistan Chambers of Commerce and Industry (FPCCI) oversees the functioning of chapters of chamber of commerce and industry (CCIs), and trade associations (TAs) in entire Pakistan. FPCCI inaugurated its external offices in Chengdu and Kuming cities in China. It maintains rapport with overseas chambers, TAs, trade promotion agencies, international exhibitors, trade consultants overseas, and foreign embassies and counsels. It also imparts valuable trade records, statistics, and insights to the foreign counterparts. The private sector organizations publish trade directory of Pakistan, so-called 'Yellow Pages,' which publishes info about contact details of various domestic businesses, associations, trade bodies, authorities, departments, ministries, banks and financial institutes, travel and tourism info, embassies and high commissions, and so forth.

\subsubsection{Trade-related Collaboration of Public and Private Sectors}

Various initiatives have been taken regarding collaboration of public and private sectors (and specifically corporate-government collaboration) for the sake of developing foreign trade and commerce, bringing investment to Pakistan, and facilitating international firms of Pakistan, and those intending to go for worldwide expansion. Meetings, deliberations, and conferences take place among all key stakeholders of the public and private sectors. Examples of key stakeholders_consists of Ministry of Commerce (MoC), Ministry of Industries and Production (MoIP), Ministry of Textile (MoT), Ministry of Foreign Affairs (MoFA), Trade Development Authority of Pakistan (TDAP), Trading Corporation of Pakistan (TCP), Board of Investment (BoI), State Bank of Pakistan (SBP), Securities and Exchange Commission of Pakistan (SECP), and Small and Medium Enterprise Development Authority (SMEDA) from the public sector and Federation of Pakistan Chambers of Commerce and Industry (FPCCI), chapters of chamber of commerce and industry (CCIs), and trade associations (TAs) operative at national scale, for instance, textile sector's representative body, All Pakistan Textile Millers Association 
(APTMA), rice sector's representative body, Rice Exporters Association of Pakistan (REAP), etc. from the private sector.

As Federation of Pakistan Chambers of Commerce and Industry (FPCCI) is the prime body representing trade and industry in Pakistan, all the chapters of chamber of commerce and industry (CCIs), and trade associations (TAs) operative at national scale, so it plays an utmost essential role in partnering with the public sector authorities. FPCCI engages itself in various activities, campaigns, and programs throughout the year. It receives trade leads from TDAP and various sources and publishes them electronically to aid its members and especially exporters cum globally expanding companies based in Pakistan. It organizes trade shows and expos along with TDAP, MoC, and other bodies to introduce Pakistani products to world market, providing them market access and on-spot-sale, and assisting them in developing linkages and networking with worldwide buyers and suppliers. It organizes events, meetings, and conferences to attract investment and specifically foreign direct investment (FDI), removing any trade sanctions/embargoes cum barriers, and promoting multilateral trade of the country with other countries.

Moreover, it highlights issues of the business community to the public authorities and international organizations including international developmental agencies, so-called international non-governmental organizations (INGOs). It works with them and assists the government in all spheres of life. It has official representation at various public and private forums. It organizes events like export trophy awards, achievement awards, etc. to recognize the prominent exporters (inclusive of those that have overseas subsidiaries) and those businesspersons that have tremendous services for the country. It aids the government in preparing its policy framework and legitimate system governing business. It annually prepares trade policy and federal budget proposals for the consideration of the government bodies. In addition, it continues its excellent services by regularly engaging itself in research and development $(\mathrm{R} \& \mathrm{D})$ activities. Above all, it serves the national community in the unfortunate events of natural calamities, famine, drought, heavy rains cum floods, earthquakes, and the like. It also develops its youth and working class, hence imparts them training and development to fortify their skills and occupational cum professional competencies.

The public and private sector organizations share the common goal of thriving exports and foreign business, along with attracting FDI. They cooperate and coordinate on issues of organizing and taking part in expos and conferences inside and outside the country, such as 'Pakistan's Single Country Exhibition, titled as, Made in Pakistan.' These stakeholders exchange views, insights, and deliberate on regulatory affairs along with policies in a bid to resolve problems encountered by exporters and Pakistani companies expanding globally. But the reality is very bitter and harsh.

Recently ministry of commerce (MoC) and Trade Development Authority of Pakistan (TDAP) organized a conference to deliberate about export strategies of Pakistan for all the continents, United States of America, Europe, Australia, Asia, and Africa. They invited their commercial consular/attaches placed all over the world, and also invited the business community through Federation of Pakistan Chambers of Commerce and Industry (FPCCI) as well as academia. In independent sessions, they made a discourse about existing export strategies, future course of direction, and the global best practices inclusive of the models of China and India (that how they support their companies in global trade). The business community and academia 
soon observed discrimination, bias, and bureaucratic red tapes on the part of government officials of MoC and TDAP. They dominated the discourse and declined most of the proposals raised by the private sector (personal communication with Dr Umad Mazher of SZABIST and Dr Ather Illahi of IBA with the $1^{\text {st }}$ author of this study who also eye witnessed and participated in that session).

\subsection{Challenges in Public-Private Assistance and Global Expansion of Pakistani Companies}

In nexus with public-private collaboration aimed at provision of supportive framework to globally expanding Pakistani companies, the two relevant terms used with institutional influences are institutional voids and institutional uncertainty. Institutional voids refer to dearth of supportive network, which paves the way to success for international companies (Santangelo and Meyer, 2011; Khanna and Palepu, 2010). Institutional uncertainty refers to the volatile policies or rapidly changing institutional rules governing businesses (Santangelo and Meyer, 2011; Delios and Henisz, 2003). Mintzberg and Waters (1985) stated that lack of complete information combined with the experience of operating in an unpredictable environment cause firms to devise imposed strategies, which tend to be similar to emergent strategies, rather than a well-planned strategy. In situations where institutional voids exist in foreign operations, firms need to pay utmost salience to pre-entry information; otherwise they face greater risks and post-entry costs (Santangelo and Meyer, 2011).

Due to institutional voids and uncertainties, many of the foreign and even domestic companies divested their business interests from Pakistan (Qureshi, 2014). The challenges encountered by Pakistani companies within the domestic markets (for which mainly the public entities hold liability) include the law and order, crises, growing electricity and gas outages, ever-escalating oil, petroleum products, and electricity prices, and depreciating Pak rupee value, which substantially contribute to transportation cost, rapidly growing inflation and increasing cost of doing business, high interest rates on borrowing, and the serious issues of extremism, and terrorism. Some other challenges are presented from the Trade Policy of Pakistan for the years 2009-12 (Ministry of Commerce, 2012; Trade Development Authority of Pakistan, 2012): infrastructure crises, particularly in energy resulting in electricity and gas outages; lack of research, inventions, innovations, and technological infrastructure; low levels of value addition in manufacturing industries; low labor productivity due to manual and less skilled work; poor economies of scale in the Small and Medium Enterprise (SME) sector; lack of diversification in exports for new product categories and geographies; and little Foreign Direct Investment (FDI) in manufacturing and exportable sectors.

\subsection{Conceptual Framework}

The conceptual framework for the probe is displayed in the figure 2.1 below. It exhibits predictor variables (including public institutions' support, private institutions' support, and public-private collaboration) that exert an impact on the outcome variable, corporate globalization. 
Figure 2.1

An Integrated Framework on Corporate Globalization and Public-Private Support cum Collaboration

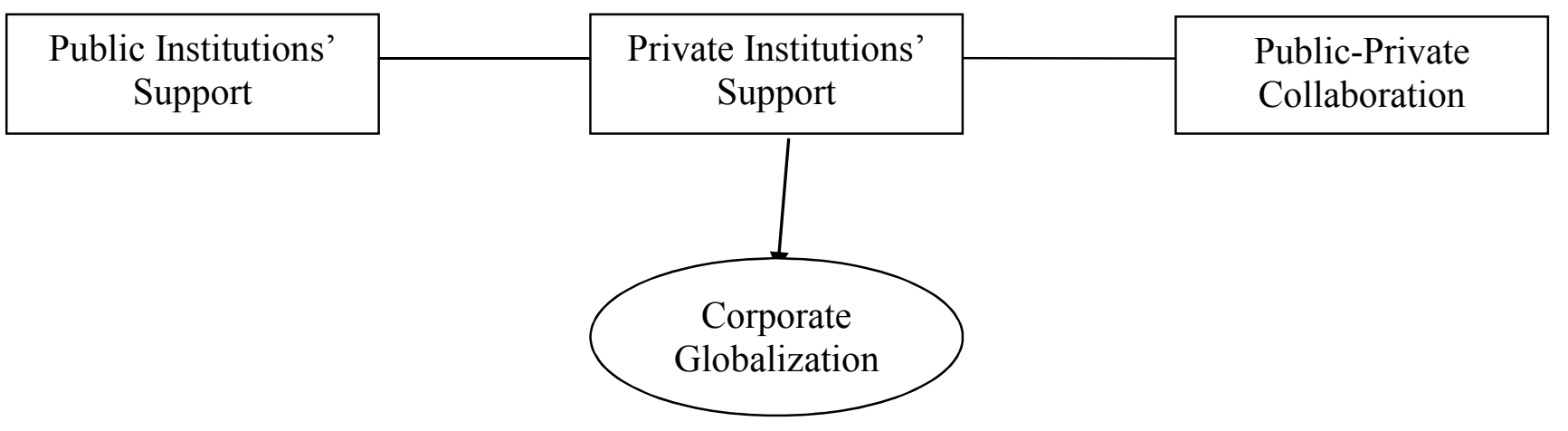

Note that the variables of the conceptual framework (illustrated in figure 2.1 on previous page) were spelled out in the literature review presented earlier.

\subsection{Research Hypotheses}

Based on the conceptual framework, the hypotheses under investigation are depicted beneath:

H1. Public institutions' support (technical and financial) has significant and positive impact on corporate globalization (or global expansion).

H2. Private institutions' support (technical and financial) has significant and positive impact on corporate globalization.

H3. The public-private collaboration in Pakistan has significant and positive impact on corporate globalization.

\section{DATA ANALYSIS}

The data is collected mainly from primary, secondary, and tertiary sources for analysis. Primary data is obtained through interviews from participants in three distinct categories of samples, which is interpreted qualitatively. Observations through media content analysis also take place to discover facts and findings about corporate globalization of Pakistani companies.

\subsection{Interpretation of Interviews}

These interviews were conducted with Exporters and Globally Expanding Pakistani Companies and officials of ministry of commerce and Trade Development Authority of Pakistan)

In nexus with the type of incentives (technical and financial) they avail from ministry of commerce (MoC), Trade Development Authority of Pakistan (TDAP), or other public bodies for exporting their products abroad, majority of participants expressed that the government institutions like MoC and TDAP support them technically and financially by providing updated trade statistics, discovering potential markets, developing linkages abroad, holding 
expos, offering subsidies in participating in foreign expos, and maintaining liaison with overseas counterparts, but this calls for establishing solid linkages with government agencies and trade facilitating agencies. In addition, they assist by providing relatively cheap export financing, offer support in Research and Development (R\&D), opening offices abroad, subsidy claims for travelling, boarding, and lodging outgoings to attend foreign expos and trade or investment conferences, sales tax refunds, duty drawbacks, and so forth. But many of them expressed their grievances and complaints that the Government does not keep up its promises, and there is a very pathetic role of TDAP and MoC in nourishing overseas commerce.

What it pledges seems only a wonderful dream for many, but on the other side, there are many companies who enjoy being the beneficiaries as they receive such subsidies and grants. They opined that they adhere to the rules or procedures devised by TDAP and persistently follow the matters of such claims. Regarding the matters of difficulties to avail such incentives, many of the participants lodged their grievances about receiving claims of subsidies and grants from the Government. Unfortunately thousands of claims of many exporters fall pending despite fulfilling the mandatory requirements and approbations of their trade body or FPCCI. However, the export development fund (EDF) was generated from exporters' receipts. Another salient issue was about the collaboration between the public and the private sector institutions and more specifically corporate-government collaboration to initiate any programs for providing incentives to exporters including those that expand globally.

The participants in aggregate briefed that although there appears meaningful collaboration and cooperation between public and private sectors to uphold exporters and corporate global expansion of the domestic concerns, but there exists dearth of trust on both sides. The private sector does not count on the public sector as a result of volatile policies, unstable legal-political scenario, and issues of transparency and good governance on the part of the Government. While the public sector does not count on the private sector as a result of cases of tax evasions, unfair savings in duties and refunds, and other frauds, illicit actions, and immoral practices. In the $2^{\text {nd }}$ phase, interviews were conducted from officials of particular public bodies.

The public entities including MoC and TDAP also agreed with the statements of the private sector regarding hand-holding mechanism of the government tailor-made for its exporters and globally expanding companies, and briefed further schemes, but they contradicted regarding the disgruntled businessmen's complaints about non-receipt or pending claims of subsidies and grants. They argued that troubles only emanate when the documentary formalities are not fulfilled altogether, otherwise there appear no issues. The government is extending its arms and take into confidence i.e. collaborate with the private sector or all stakeholders prior to planning and executing its policies and programs.

\subsection{Observations through Media Content Analysis}

Observation took place especially to notice public-private entities' collaboration and cooperation. There have been testimonies about global expansion of many Pakistani companies. But there are incidences of relocation and disinvestments too. Many textile millers of Pakistan relocated to Bangladesh to get rid of turmoil in Pakistan, while many expanded overseas including USA (Jafri, 2012 [published in Business Recorder]; Dawn, 2010, 2013). About $40 \%$ of the textile industry of Pakistan relocated to Bangladesh within past five years 
(from 2008-2012), which was also stated by Makhdoom Shahabuddin, the former textile minister (Ahmad, 2012; Azad, 2012; Jafri, 2012; Syed, 2011). Due to severe crises, some giant multinational pharmaceutical companies also divested and dissolved their business interests in Pakistan (Abduhu, 2013; Khan, 2013). Unfortunately, 80\% of the promises of the Government regarding these subsidies go unfulfilled (Dawn, 2012), and many of them believe in the fairness of that report. While some believe in another report that the Government reimbursed claims for Rs3 billion plus to exporters in 2011-12, while about $30 \%$ claims appear yet pending (Daily Express News, 2012). It released 600 million plus rupees claims to them in the head of duty drawback claims (Dawn, 2013).

The Government has failed to address the core concerns of the private sector like handling energy crises, degenerating law and order situation, unstable policies, rampant corruption, depreciating Pak rupee value, rapidly escalating inflation, and cost of doing business. Thus it impedes the potential domestic companies to move for global expansion. Another shocking news is, in past six years, the government has deviated funds disbursement for Rs 15 billion from export development fund (EDF-established from exporters' own revenues) to expenditure deficit account. Recently, the Federal Board of Revenue (FBR) diagnosed a fraud for Rs63 billion on accounts of false claims for sales tax refunds (Ibid, 2013; Ghumman, 2013). Another mega scam of Rs760 million was disclosed at Trade Development Authority of Pakistan (TDAP), (Khan, 2013a, 2013b). Some of its top executives established fake export companies, to whom millions of rupees were granted over night on account of subsidies and grants for opening offices, retail outlets, and warehouses abroad, and for freight subsidy. Criminal investigations are underway by anti corruption agencies (Ghumman, 2013 [Business Recorder]; Khan, 2012).

\subsection{Quantitative Data Analysis}

The results of the quantitative analysis are presented beneath:

Table 3.1

Reliability Statistics

[Cronbach's Alpha (CA) and $\mathrm{N}$ of Items (Variables)]

\begin{tabular}{|r|r|r|r|r|r|r|r|r|r|r|r|}
\hline$[1] \mathrm{C}$ & {$[2] \mathrm{N}$} & {$[3] \mathrm{C}$} & {$[4] \mathrm{N}$} & {$[5] \mathrm{C}$} & {$[6] \mathrm{N}$} & {$[7] \mathrm{C}$} & {$[8] \mathrm{N}$} & {$[9] \mathrm{C}$} & {$[10] \mathrm{N}$} & {$[11] \mathrm{C}$} & {$[12] \mathrm{N}$} \\
$\mathrm{A}$ & & $\mathrm{A}$ & & $\mathrm{A}$ & & $\mathrm{A}$ & & $\mathrm{A}$ & & $\mathrm{A}$ & \\
\hline$[13] .9$ & {$[14] 1$} & {$[15] .9$} & {$[16] 4$} & {$[17] .8$} & {$[18] 3$} & {$[19] .8$} & {$[20] 3$} & {$[21] .8$} & {$[22] 3$} & {$[23] .8$} & {$[24] 9$} \\
7 & 5 & 6 & & 5 & $(\mathrm{PI}$ & 4 & $(\mathrm{PR}$ & 4 & $(\mathrm{PP}$ & 0 & $(\mathrm{C}$ \\
1 & & 0 & & 1 & $\mathrm{~S})$ & 5 & $\mathrm{IS})$ & 1 & $\mathrm{C})$ & 7 & $\mathrm{G})$ \\
\hline
\end{tabular}

The table 3.1 exhibited above has splendid reliability of the measurement scale. The score of $<$ Cronbach Alpha stands $=.977>$ with 15 items is greater than the benchmark of .70 , suggesting that it's highly reliable for data analysis. In addition, it portrays that when number of items/variables was 4 , the score stood .967 . The individual scores of all the variables fall between the ranges of .807 to .851 , which means they tend to be highly reliable. 
Table 3.2

Model Summary and ANOVA (of Multiple Regression Analysis)

\begin{tabular}{|l|l|l|l|l|l|}
\hline$[25] \mathrm{R}$ & {$[26] \mathrm{R}$ Square } & $\begin{array}{l}\text { [27] Adjusted } \\
\text { Square }\end{array}$ & $\mathrm{R}$ & $\begin{array}{l}\text { [28] Std. Error of } \\
\text { the Estimate }\end{array}$ & {$[29] \mathrm{F}$} \\
\hline$[31] .853^{\mathrm{a}}$ & {$[32] .704$} & {$[33] .702$} & {$[34] .40622$} & {$[35] 158.226$} & {$[36] .000^{\mathrm{a}}$} \\
\hline
\end{tabular}

Table 3.3

Coefficients

\begin{tabular}{|l|l|l|l|}
\hline$[37]$ Variables & {$[38] \mathrm{B}$} & {$[39] \mathrm{t}$} & {$[40]$ Sig. } \\
\hline$[41]$ Constant & {$[42]$} & {$[43] 3.152$} & {$[44] .002$} \\
\hline $\begin{array}{c}{[45] \text { Public institutions' }} \\
\text { support }\end{array}$ & {$[46] .371$} & {$[47] 3.245$} & {$[48] .001$} \\
\hline $\begin{array}{c}{[49] \text { Private institutions' }} \\
\text { support }\end{array}$ & {$[50] .345$} & {$[51] 3.221$} & {$[52] .001$} \\
\hline $\begin{array}{c}{[53] \text { Public-private }} \\
\text { collaboration }\end{array}$ & {$[54] .342$} & {$[55] 3.114$} & {$[56] .001$} \\
\hline
\end{tabular}

a. Dependent Variable: Corporate Globalization

The tables 3.2 and 3.3 presented above display R values, ANOVA and Coefficients. In table 3.2 , the $\mathrm{R}$ values of the model that states the coefficient of determination or the effect of the predictors over the criterion variable. The $\mathrm{R}$ score is $<\mathrm{R}=.853>$, with $\mathrm{R}$ square value of $<\mathrm{R} 2=$ $.704>$, and adjusted $\mathrm{R}$ square for $\angle \mathrm{AR} 2=.702>$, which suggests the predictors explains the criterion variable by $70 \%$. The significance level of the model that is $<$ sig. $=.000>$ and the $\mathrm{F}$ value is $\langle F=158.226>$, which is in the acceptance region. Hence the result shows the overall model fit. The table 3.3, the results show Beta values of all the independent variables that had $t$ scores that are greater than the cut off value of 2 with the significance level that is less than .05 . Hence, all of the predictors appear significant. On the basis of the results driven from Multiple Regression Analysis, all the hypotheses are accepted.

Table 3.4

ANOVA

\begin{tabular}{|l|l|l|l|l|l|}
\hline$[57]$ & $\begin{array}{c}{[58] \text { Sum of }} \\
\text { Squares }\end{array}$ & {$[59] \mathrm{Df}$} & $\begin{array}{c}\text { [60] Mean } \\
\text { Square }\end{array}$ & {$[61] \mathrm{F}$} & {$[62]$ Sig. } \\
\hline $\begin{array}{c}{[63] \text { Between }} \\
\text { Groups }\end{array}$ & {$[64] .047$} & {$[65] 1$} & {$[66] .047$} & {$[67] 1.480$} & {$[68] .062$} \\
\hline $\begin{array}{c}{[69] \text { Within }} \\
\text { Groups }\end{array}$ & {$[70] .127$} & {$[71] 3$} & {$[72] .042$} & {$[73]$} & {$[74]$} \\
\hline$[75]$ Total & {$[76] .174$} & {$[77] 4$} & {$[78]$} & {$[79]$} & {$[80]$} \\
\hline
\end{tabular}

The table 3.4 shows the value of significance of results, $<$ sig. $=.062>$ means it's insignificant. The $\mathrm{F}$ statistics is $\langle F=1.480>$, implying that the means of varying populations are the same.

The discussion of findings (from qualitative cum quantitative modes of enquiry) focuses the bottom lines that the public and private sectors recognize the impact of technical and financial assistance to exporters and globally expanding companies of Pakistan. The public sector trade 
development bodies provide such assistance in the shape of incentives, grants, and subsidies of various types, and relatively cheaper financing. However, these steps are far below the expectations of the private sector, which has been taking initiatives to upgrade technical capacities of such companies and resolving their financial issues. In nutshell, the public-private collaboration is infirm and premature.

\section{CONCLUSION AND RECOMMENDATIONS}

This section concludes the enquiry, proposes suggestions for the consideration of practitioners and policy makers, and depicts the scope and delimitations of the probe.

\subsection{Conclusion}

- Many textile companies, leather and food business companies, service providing concerns, banks, and pharmaceutical companies have overseas physical infrastructure to run their businesses abroad, which implies that corporate globalization (or expansion) surges in Pakistan. However, incidences of relocation and divestiture also take place, as a substantial proportion of textile industries relocated to Bangladesh in the wake of energy and law and order crises, ever-escalating corruption, unstable policy framework, and mis-governance. Due to these reasons, some multinational pharmaceutical companies wounded up their operations from Pakistan, and even the indigenous people avoided investing in business.

- There are evidences of lack of support from public sector entities, as many of the globally expanding Pakistani companies and exporters receive substantial benefits from schemes of duty drawbacks, sales tax refunds, export financing at subsidized interest, allowances in attending foreign expos, and funds for developing exports and overseas markets. However, there are several cases where individual exporters including globally expanding companies from Pakistan are claiming for their long-awaited pending claims, but the authorities maintain about the un-adherence to the formally laid down procedures. On the contrary, there are evidences of support from private sector entities on self-help basis. There seems partial existence of collaboration and cooperation of public-private sectors (and more specifically corporate-government collaboration) having lack of mutual trust and dissonance over cooperation, since the private sector sounds frustrated of the volatile and un-friendly policies executed by the public sector. On the other hand, there are several incidences of frauds at Trade Development Authority of Pakistan (TDAP) about bogus releases of subsidy claims to exporters and globally expanding companies, and mishandling of export funds by ministry of finance (MoF), as investigated by federal anti corruption agencies and the scams are exposed by prominent and relatively reliable media forces.

\subsection{Recommendations}

Although the government and particularly the trade promoting authorities usually devise proactive and modern policies and programs for such companies by keeping in view the global best practices, but their execution is undermined, unfair, and full of rampant corruption (in most cases). The apex organizations like Trade Development Authority of Pakistan (TDAP) and ministry of commerce $(\mathrm{MoC})$ should discourage any bureaucratic red tapes, streamline their procedural requirements, and exemplify a business-friendly facilitation system. 
They should genuinely consult, coordinate, and cooperate with the private sector trade bodies prior to framing and executing policies and programs for them, and must set short to long-run plans for them along with a road map for fund raising to accomplish strategic objectives. The private sector bodies should also find their ways out through their own as well as global sources. Such a strategic partnership among the both sectors also calls for understanding and mutual trust, and above all transparency and good governance at two sides. In addition, the public sector (in collaboration with the private one) should ink more meaningful free/preferential trade agreements (F/PTAs) with foreign governments and seek market access. This way the Pakistani globally expanding companies and exporters can avail reduced tariffs and non-technical barriers to trade, ensure market access, and exploit generalized system of preference (GSP) plus from donor countries.

\section{REFERENCES}

Abduhu, S. (2013, September 04). Anti-investment mood forcing multinationals to close pharma units. Pak Observer. Retrieved from http://pakobserver.net/

Ahmad, M. (2012, July 03). Value-added textile entrepreneurs relocating businesses to Bangladesh. The News. Retrieved from http://www.thenews.com.pk/

Anjum, M. A. (2011). Illusive and Regressive Globalization: Issues and Challenges for Pakistan Economy. International Journal of Business and Social Sciences, 2(5), 67-76.

Azad, A. R. (2012, September 13). Energy woes: over 40 percent of textile industry has shifted to Bangladesh? Business Recorder. Retrieved from http://www.brerecorder.com/

Daily Express. (2012, July 9). The Promises of government with exporters go unfulfilled.

Dawn. (2010, Sept 23). Nishat mills to set up subsidiary in UAE.

Dawn. (2012, July 8). The Promises of government with exporters go unfulfilled.

Dawn. (2013, March 13). Government released duty drawback claims to exporters, 11.

Delios, A., \& Henisz, W. J. (2003). Political hazards, experience and sequential entry strategies: The International expansion of Japanese firms 1980-1998. Strategic Management Journal, 24 , 1153-1164.

European Commission. (2005). Globalization and Internationalization. Retrieved from www.phil.muni.cz/.../internationalization-and-globalization-theory.doc

Federation of Pakistan Chambers of Commerce and Industry. (2012). An Overview of FPCCI. Retrieved from www.fpcci.com.pk/

Ghumman, M. (2013, August 2). Fake Claims: three TDAP officials may be investigated by FIA. Business Recorder. Retrieved from www.brecorder.com/business-a-economy/189/1217217

Ghumman, M. (2013, August 8). Incentive schemes: Commerce Ministry identifies 'fraudulent' companies. Business Recorder. Retrieved from www.brecorder.com/top-stories/0/1218899

Gilman, N., Goldhammer, J., \& Weber, S. (2011). Deviant Globalization: Black Market Economy in the $21^{\text {st }}$ Century. New York, NY: Continuum International Publishing Group.

Hill, C. W. (2005). International Business - Competing in the Global Marketplace, New Delhi: Tata McGraw-Hill Publishing Company Limited.

Hill, C. W. L. (2006). Global Business Today (4 ${ }^{\text {th }}$ ed.). Boston: McGraw Hill/Irwin.

International Monetary Fund. (2014). An Overview of IMF. Retrieved from www.imf.org/ 
Jafri, O. (2012, Jan. 31). High profits encourage textile industry to shift to Bangladesh. Retrieved from http://defence.pk/threads/

Jeffus, W. M. (2003). Survey of the Theories of Globalization. Retrieved from wendyjeffus.com/images/Globalization.doc

Johanson, J. \& Vahlne, J.-E. (2009). The Uppsala internationalization process model revisited: From liability of foreignness to liability of outsidership. Journal of International Business Studies, 40, 1411-1431. Retrieved from doi:10.1057/jibs.2009.24

Khan, A. (2013, September 04). Law \& order Poor conditions forcing MNCs to quit Pakistan. The Nation. Retrieved from http://www.nation.com.pk/pakistan.

Khan, M. Z. (2012, Dec. 14). Bogus firms receive Rs63 bn refunds. Dawn. Retrieved from http://beta.dawn.com/news/771336/bogus-firms-receive-rs63bn-refunds

Khan, M. Z. (2013, August 1). Ministry claims unearthing Rs760 million scam in TDAP. Dawn.

Khan, M. Z. (2013, March 10). Rs15 billion export funds diverted. Dawn.

Khanna, T. \& Palepu, K. (1997). Why confused strategies may be wrong for emerging markets? Harvard Business Review, 75(4), 41-48.

Li, S., Qiu, J., \& Wan, C. (2011). Corporate Globalization and Bank Lending. Journal of International Studies, 342(9), 1016-1042. Retrieved from www.jibs.net

Luca, M. (2013). How many interviews are needed in a qualitative research? Is there any rule or popular practice? Retrieved from http://www.researchgate.net/post/

Ministry of Commerce. (2013). List of FTAs and PTAs of Pakistan with Other Countries. Retrieved from www.commerce.gov.pk

Ministry of Commerce. (2013). Strategic Trade Policy Framework of Pakistan (2012-2015). Retrieved from www.commerce.gov.pk

Ministry of Commerce. (2014). An Overview of Ministry of Commerce. Retrieved from www.commerce.gov.pk

Mintzberg, H, \& Waters, J. A. (1985). Of strategies, deliberate and emergent. Strategic Management Journal, 6(3), 257-272.

Nike (2014)._An Overview of Nike. Retrieved from www.nike.com

Pakistan Bureau of Statistics. (2013). Pakistan Statistical Year Book 2012. Retrieved from http://www.pbs.gov.pk/content/pakistan-statistical-year-book-2012

President of Pakistan. (2013). List of FTAs and PTAs of Pakistan with Other Countries. Retrieved from www.presidentofpakistan.gov.pk

Qureshi, J. A. (2014). Corporate Global Expansion: Challenges and Strategies for Pakistani Companies. PhD Dissertation. Shaheed Zulfikar Ali Bhutto Institute of Science and Technology, Karachi.

Santangelo, G. D. \& Meyer, K. E. (2011). Extending the internationalization process model: Increases and decreases of MNE commitment in emerging economies. Journal of International Business Studies, 42(7), 894-909. Retrieved from www.jibs.net

Saunders, M., Lewis, P., \& Thornhill, A. (2011). Research Methods for Business Students (4 ${ }^{\text {th }}$ ed.). Delhi: Pearson Education Limited.

Securities \& Exchange Commission of Pakistan. (2013). Number of Limited Companies in Pakistan. Retrieved from www.secp.gov.pk

Statistics Division. (2010-11). Pakistan Economic Survey. Ministry of Finance, Pakistan.

Statistics Division. (2011-12). Pakistan Economic Survey. Ministry of Finance, Pakistan. 
Statistics Division. (2012-13). Pakistan Economic Survey. Ministry of Finance, Pakistan.

Syed, R. (2011, November 1100). Textile units moving to Bangladesh. Daily Times. Retrieved from http://www.dailytimes.com.pk/

Trade Development Authority of Pakistan (2013). Strategic Trade Policy Framework of Pakistan (2012-2015). Retrieved from www. tdap.gov.pk

Trade Development Authority of Pakistan. (2014). An Overview of Trade Development Authority of Pakistan. Retrieved from www. tdap.gov.pk

Trivett, V. (2011, June 27). Business Insider. Retrieved from http://www.businessinsider.com/25corporations-bigger-tan-countries-2011-6?op=1

World Trade Organization. (2014). An Overview of WTO. Retrieved from http://www.wto.org/

Zheng, J. Roehrich, J. K. \& Lewis, M. A. (2008). The dynamics of contractual and relational governance: Evidence from long-term public-private procurement arrangements. Journal of Purchasing and Supply Management, 14(1), 43-54. 